\title{
Effects of hypoxia on predator-prey dynamics of the blue crab Callinectes sapidus and the Baltic clam Macoma balthica in Chesapeake Bay
}

\author{
R. D. Seitz ${ }^{1, *}$, L. S. Marshall Jr${ }^{2}$, A. H. Hines ${ }^{3}$, K. L. Clark $^{3}$ \\ ${ }^{1}$ Virginia Institute of Marine Science, The College of William and Mary, PO Box 1346, Gloucester Point, Virginia 23062, USA \\ ${ }^{2}$ Biology Department, Room 166, Key Hall, Morgan State University, Baltimore, Maryland 21251, USA \\ ${ }^{3}$ Smithsonian Environmental Research Center, PO Box 28, Edgewater, Maryland 21037, USA
}

\begin{abstract}
In general, hypoxia $\left(<2 \mathrm{mg} \mathrm{O}_{2} \mathrm{l}^{-1}\right)$ is detrimental to marine food webs because of faunal declines associated with persistent, severely low oxygen. However, transfer of benthic production to higher trophic levels could be facilitated under hypoxia if infauna migrate to shallower burial depths, increasing their availability to predators. A series of outdoor mesocosm and laboratory experiments were conducted in 3 years (1999 to 2001) to quantify the effects of hypoxia upon (1) predation by the blue crab Callinectes sapidus on the Baltic clam Macoma balthica, a biomass dominant in Chesapeake Bay, and (2) burial depth and survival of $M$. balthica. For the predation experiments, $12 \mathrm{M}$. balthica were transplanted into replicate $1200 \mathrm{l}$ mesocosms at 48 clams $\mathrm{m}^{-2}$ under normoxia $\left(>8 \mathrm{mg} \mathrm{O}_{2} \mathrm{l}^{-1}\right.$ ) or low dissolved oxygen (low $\mathrm{DO}_{;}<2 \mathrm{mg} \mathrm{O}_{2} \mathrm{l}^{-1}$ ) either without or with a male blue crab that was allowed $2 \mathrm{~d}$ to feed upon the clams. Predation-induced proportional mortality of clams was significantly lower under low DO than under normoxia in all 3 years. Thus, under short-term hypoxia, both crab feeding efficiency and trophic transfer from $M$. balthica to blue crabs were reduced. Changes in clam burial depth due to oxygen levels was determined by establishing normoxic and low DO treatments in replicate 2081 aquaria in 2 years. Burial depth after exposure to oxygen treatments for $48 \mathrm{~h}$ did not differ as a function of oxygen level. None of the clams died after $2 \mathrm{~d}$ of low DO, $27 \%$ died after $\sim 6 \mathrm{~d}$, and $90 \%$ died after $21 \mathrm{~d}$. Short-lived hypoxia therefore reduces the ability of crabs to forage upon clams efficiently and increases clam survival, whereas long-term hypoxia may increase the availability of clam prey to predators through mortality and movement to the surface. Thus, shortlived hypoxia is likely to reduce the transfer of benthic prey to higher trophic levels, although longerterm exposure may increase transfer.
\end{abstract}

KEY WORDS: Hypoxia $\cdot$ Dissolved oxygen $\cdot$ Callinectes sapidus $\cdot$ Blue crab $\cdot$ Macoma balthica $\cdot$ Baltic clam $\cdot$ Predator-prey $\cdot$ Chesapeake Bay $\cdot$ Benthos

Resale or republication not permitted without written consent of the publisher

\section{INTRODUCTION}

The role of environmental perturbations, such as anoxia $\left(0 \mathrm{mg} \mathrm{O}_{2} \mathrm{l}^{-1}\right)$ and hypoxia $\left(<2 \mathrm{mg} \mathrm{O}_{2} \mathrm{l}^{-1}\right)$, in determining the outcome of food web dynamics is poorly known (Breitburg 1992, Diaz \& Rosenberg 1995, Breitburg et al. 1997, Rabalais \& Turner 2001). Hypoxic and anoxic zones are increasing in areal extent and duration in marine systems with increases in anthropogenic influences such as eutrophication (Rosenberg \& Loo
1988, Rabalais et al. 1994), and further worsening of conditions due to global warming or escalated anthropogenic influences may alter the productivity base needed for important fishery species (Diaz \& Rosenberg 1995). In general, hypoxia is detrimental because of faunal reductions associated with persistent severe hypoxia (Holland et al. 1977, Stachowitsch 1984). However, transfer of benthic production to higher trophic levels may be facilitated in areas of low dissolved oxygen because of the migration of infauna to shallower burial 
depths (Diaz et al. 1992). In this study, we examined whether short-lived hypoxia is beneficial or detrimental to dominant benthic organisms in Chesapeake Bay.

\section{Hypoxia in Chesapeake Bay}

In Chesapeake Bay, hypoxia typically occurs in summer, in association with algal blooms and stratification of the water column (Haas 1977, Officer et al. 1984, Seliger et al. 1985). Within Chesapeake Bay, the York River experiences 2 to 3 hypoxic events each summer which characteristically last days to weeks (Pihl et al. 1991), whereas certain areas of the Rappahannock River may suffer anoxia for months (Llansó 1992). Such hypoxic events can either stress or kill resident organisms (e.g. Holland et al. 1987, Breitburg 1992, Dauer et al. 1992, Diaz et al. 1992, Breitburg et al. 1997). These short, episodic, hypoxic events in the lower York River (Officer et al. 1984) helped determine a realistic duration for our experimental investigations of predatorprey interactions under hypoxia.

The specific ecological effects of low dissolved oxygen on the benthos depend on the duration and amplitude of the events. Short-lived hypoxia may not have severe consequences for the biota, and the resident species may develop a tolerance to periodic stress (e.g. York River; Pihl et al. 1991). Alternatively, many infaunal species are physiologically stressed, emerge from the sediments during hypoxia (Steimle \& Radosh 1979, Jørgensen 1980, Stachowitsch 1984, Diaz et al. 1992, Nilsson \& Rosenberg 1994), and may be exploited by epibenthic predators during less severe hypoxia (Pihl et al. 1992, Nestlerode \& Diaz 1998, Taylor \& Eggleston 2000).

\section{Behavioral responses to hypoxia}

Organisms have developed behavioral responses associated with hypoxia that enable them to survive under adverse conditions. Often, the first response of a mobile organism is to increase its respiration rate, or migrate away from hypoxic areas (Pihl 1989, Baden et al. 1990, Pihl et al. 1991, Lenihan et al. 2001). In response to hypoxia, some organisms stretch their siphons or arms (Jørgensen 1980) into the water column, where oxygen concentrations are higher. For example, during hypoxia Macoma balthica in Danish fjords (Jørgensen 1980) and Mya arenaria in North Carolina (Taylor \& Eggleston 2000) extend their siphons, making them vulnerable to epibenthic predators. Mild hypoxia ( 2 to $3 \mathrm{mg} \mathrm{l}^{-1}$ ) may only cause mortality in sensitive infauna (e.g. crustaceans and echinoderms), whereas severe hypoxia $\left(\sim 1 \mathrm{mg} \mathrm{l}^{-1}\right)$ can cause extensive mortality in many species (Hines \& Comtois 1985, Weigelt \& Rumohr 1986, Llansó 1992, Diaz \& Rosenberg 1995). By increasing susceptibility of prey to predators, hypoxia may change the population structure of macrobenthic communities (Jørgensen 1980, Breitburg 1992, Pihl et al. 1992).

\section{Ecosystem effects}

The severity and duration of hypoxia may affect trophic transfer through food webs (Breitburg 1992, Breitburg et al. 1997). In areas where hypoxia is brief, the weakened and exposed infauna may be exploited successfully by predators (Nestlerode \& Diaz 1998), whereas in habitats with severe hypoxia, fish and invertebrate predators would be physiologically stressed and unable to exploit weakened infauna (Holland et al. 1987). For example, in the York River, the level of hypoxia ( 0.2 to $0.8 \mathrm{mg} \mathrm{l}^{-1}$ ), its short duration $(2$ to $14 \mathrm{~d}$ ) and the relatively small area affected (depths $>9 \mathrm{~m}$ ) may allow exploitation of infauna by epibenthic predators (Diaz \& Rosenberg 1995). Moribund species on the sediment surface may be consumed by epibenthic predators that enter the area to feed (Pihl et al. 1992). Such 'positive' energy transfer is not enabled in areas where there is severe hypoxia (e.g. upper Chesapeake), and the benthos is killed directly and is thus unavailable to predators later in the season (Holland et al. 1987). Therefore, the effects of hypoxia could be beneficial to a predator if its prey becomes more vulnerable, or detrimental to a predator if the predator itself is adversely affected by hypoxia (Breitburg et al. 1992).

\section{Study species}

In Chesapeake Bay, the infaunal clam Macoma balthica is a facultative deposit and suspension feeder which can burrow to $\sim 30 \mathrm{~cm}$ in depth (Hines \& Comtois 1985, Hines et al. 1990). This species dominates benthic biomass and contributes substantially to trophic transfer through the benthic-pelagic food web (Holland et al. 1987, Baird \& Ulanowicz 1989, Hagy 2002). $M$. balthica populations on the western and eastern North Atlantic shores are morphologically and genetically distinct (Beukema \& Meehan 1985, Meehan et al. 1989); thus, European and American populations should be studied separately. In Europe, M. balthica appears fairly tolerant to low DO: $50 \%$ of individuals survived as long as $15 \mathrm{~d}$ when oxygen with hydrogen sulfide was bubbled into closed 11 jars with ambient sediment (Henriksson 1969). The lethal dose $\left(\mathrm{LD}_{50}\right)$ for M. balthica in Germany at $0.15 \mathrm{mg} \mathrm{O}_{2} \mathrm{l}^{-1}\left(10^{\circ} \mathrm{C}, 17 \mathrm{ppt}\right)$ 
is $21 \mathrm{~d}$ (Dries \& Theede 1974). Conversely, 90\% of M. balthica and $M$. mitchelli in a $100 \mathrm{~km}^{2}$ area of the Neuse River, North Carolina, were killed when hypoxia lasted more than 3 wk (Buzzelli et al. 2002).

Mild or short-lived hypoxia may lead to behavioral responses in clams, such as extension of siphons into the water column, but behavioral modifications such as changes in burial depth of Macoma balthica are unknown. Siphon extension, subsequent siphonnipping, and resultant decreased burial depth may cause increased vulnerability of clams to epibenthic predatory fishes and crustaceans (Pihl et al. 1992). Moreover, decreases in burial velocity, as observed in a European population of M. balthica (Tallqvist 2001), may negatively impact predator avoidance.

The blue crab Callinectes sapidus plays an important role in energy transfer in estuaries (Baird \& Ulanowicz 1989) and is abundant and actively foraging from late spring through autumn in Chesapeake Bay (Hines et al. 1990). Benthic infaunal clams comprise the highest percentage of the blue crab diet (Hines et al. 1990, Mansour 1992, Ebersole \& Kennedy 1995). Although some studies have shown blue crabs to be more sensitive to low DO than their clam prey (Das \& Stickle 1993, 1994, Diaz \& Rosenberg 1995), recent studies have shown that crabs can forage in hypoxic waters in the field (G. Bell \& D. B. Eggleston unpubl. data) and can move into such zones to feed on stressed infauna (Pihl et al. 1991, Nestlerode \& Diaz 1998).

In this study, our objectives were to examine the effects of low DO on predator-prey interactions between the Baltic clam Macoma balthica and the blue crab Callinectes sapidus in Chesapeake Bay. We measured faunal responses to low DO in large 1200 l outdoor mesocosms and 2081 aquaria. Specifically, we tested the effects of hypoxia upon (1) predation by blue crabs on Baltic clams, and (2) burial depth and survival of $M$. balthica from Chesapeake Bay. We examined whether hypoxia is detrimental or beneficial to the trophic interactions between 2 major species in the Chesapeake Bay ecosystem. Our results were expected to describe changes in predator-prey dynamics under hypoxia, as was described in previous investigations in pelagic food webs and field studies at broad spatial scales. We hypothesized that crab predation would not be enhanced unless clam burial depth was reduced by hypoxia.

To examine the mechanisms underlying any changes in crab predation on clams due to hypoxia (examined in the mesocosm experiment), we determined whether Macoma balthica reduced burial depth in response to hypoxia. Some clams do reduce burial depth in response to hypoxia (e.g. Mya arenaria: Taylor \& Eggleston 2000); however, changes in burial depth of Macoma balthica with hypoxia have not been examined. Given that $M$. balthica in Europe appears fairly tolerant to low DO (Jørgensen 1980), we predicted that $M$. balthica from Chesapeake Bay would not reduce its burial depth due to hypoxic conditions.

\section{MATERIALS AND METHODS}

Crab-clam interactions. Crabs Callinectes sapidus were collected in the Rhode River, a subestuary of Chesapeake Bay, using trawls or crab traps, and clams Macoma balthica were collected with a suction dredge (Eggleston et al. 1992). Only healthy, active crabs and clams exhibiting rapid valve closure upon touching were used. Animals were held in flowing estuarine water under normoxia and natural phytoplankton levels until the beginning of the experiments. Crabs were fed clams ad libitum until $48 \mathrm{~h}$ before the predation trials began. Large mesocosm tanks $(1 \times 2 \times 0.5 \mathrm{~m} ; 1200 \mathrm{l})$ were filled with $15 \mathrm{~cm}$ of azoic muddy-sand sediment $(\sim 12.5 \%$ silt and clay) and $10 \mathrm{ppt}$ water to $\sim 20 \mathrm{~cm}$ above the sediment surface (Fig. 1). Mesocosms were located outdoors and supplied with unfiltered estuarine water from the Rhode River so that water temperatures and plankton levels were equivalent to field levels. We transplanted $12 \mathrm{M}$. balthica into a $0.25 \mathrm{~m}^{2}$ patch (48 clams $\mathrm{m}^{-2}$ ) in each mesocosm, which all had a mesh-lined bottom (for easier clam retrieval). This density falls within the natural range of adult clam densities (20 to 200 clams $\mathrm{m}^{-2}$ ) in the system (Seitz et al. 2001).

In each year, 1 of 2 oxygen treatments was randomly assigned to each mesocosm, normoxia $\left(>8 \mathrm{mg} \mathrm{l}^{-1}\right.$ ), or low DO (target level $<2 \mathrm{mg} \mathrm{l}^{-1}$ ), with 3 to 5 replicates of each (Table 1). In some cases, only 6 mesocosms were used for 1 trial with replicates for each of the 2 treat-

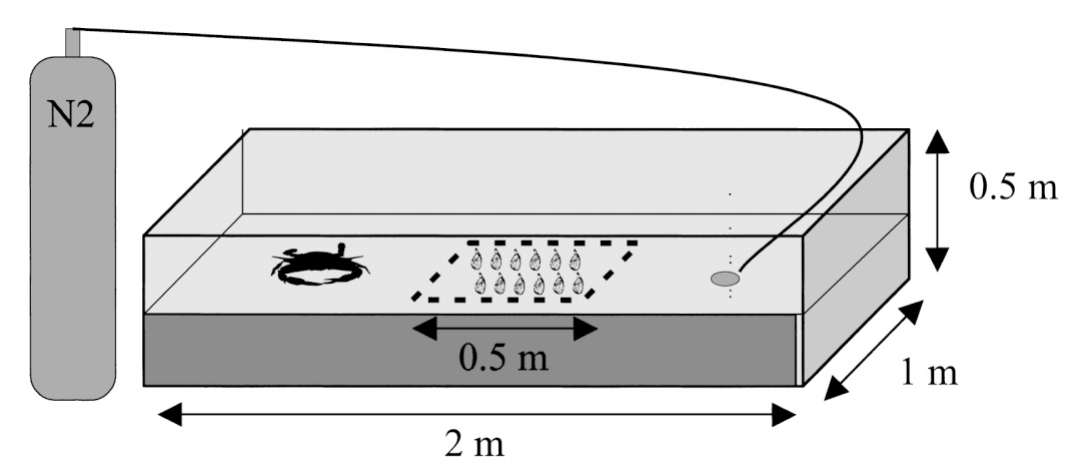

Fig. 1. Experimental set-up in crab-clam Callinectes sapidus-Macoma balthica predation mesocosm. We transplanted 12 clams into a $0.5 \times 0.5 \mathrm{~m}$ plot, resulting in $48 \mathrm{clams} \mathrm{m}^{-2}$. An air and nitrogen gas (N2) mixture was bubbled into tanks 
Table 1. Experimental framework for mesocosm deck tank experiments that examined predation by Callinectes sapidus on Macoma balthica. N: normoxia $\left(>8 \mathrm{mg} \mathrm{O}_{2} \mathrm{l}^{-1}\right)$; L: low dissolved oxygen $\left(<2 \mathrm{mg} \mathrm{O}_{2} \mathrm{l}^{-1}\right)$. In each year for each replicate, $12 \mathrm{M}$. balthica were transplanted into a $0.25 \mathrm{~m}^{2}$ patch, resulting in a density of 48 clams $\mathrm{m}^{-2}$

\begin{tabular}{|ccccccc|}
\hline $\begin{array}{c}\text { Trial } \\
\text { year }\end{array}$ & Season & $\begin{array}{c}\text { Mean } \\
\text { temperature } \\
\left({ }^{\circ} \mathrm{C}\right)\end{array}$ & $\begin{array}{c}\text { Oxygen } \\
\text { treatment }\end{array}$ & $\begin{array}{c}\text { Clam } \\
\text { density } \\
\left(\mathrm{m}^{-2}\right)\end{array}$ & $\begin{array}{c}\text { Predation } \\
\text { duration } \\
(\mathrm{h})\end{array}$ & $\begin{array}{c}\text { Replicates } \\
\text { per } \\
\text { treatment }\end{array}$ \\
\hline 1999 & Fall & 16 & N, L & 48 & 48 & 3 \\
2000 & Summer & 20 & N, L & 48 & 48 & 5 \\
2001 & Summer & 26 & N, L & 48 & 48 & 4 \\
\hline
\end{tabular}

of known length with a slightly buoyant tag was glued to the shell of each clam. In each tank, the shell length (anterior to posterior) of individual tagged Macoma balthica was measured, and the clams were buried anterior end down to the top of the shell. After acclimation to their normal burial depth and living position (71 h in 1999, $24 \mathrm{~h}$ in 2001), the monofilament line was pulled taut, and the length of line exposed above the sediment surface was measured. The clam's baseline burial depth was determined by subtracting the length of line ments; in this case, trial was used as a fixed factor and was non-significant. Since there was no significant effect of trial (within a year) on clam mortality (2000 ANOVA: $p=0.432 ; 2001$ ANOVA: $p=0.717$ ), all trials within a year were pooled. Low oxygen levels were maintained by bubbling an air and nitrogen mixture into each mesocosm, and normoxic levels were maintained by bubbling air only. These levels were monitored with a YSI DO probe $15 \mathrm{~cm}$ below the water surface and were adjusted daily. Hypoxic tanks ranged from 1.6 to $6.0 \mathrm{mg} \mathrm{O}_{2} \mathrm{l}^{-1}$, and normoxic tanks from 9.8 to $11.7 \mathrm{mg} \mathrm{O}_{2} \mathrm{l}^{-1}$, although values that deviated far from those intended were adjusted quickly. A sheet of bubble-wrap plastic was placed on the water surface of each mesocosm to limit gas exchange. Clams were allowed to acclimate to treatments for $48 \mathrm{~h}$.

In half of the replicates of each DO level, an adult male intermolt blue crab (125 to $170 \mathrm{~mm}$ carapace width) was starved for $48 \mathrm{~h}$, acclimated to hypoxic conditions $\left(\sim 2.0 \mathrm{mg} \mathrm{l}^{-1}\right)$ for $24 \mathrm{~h}$, and added randomly to a mesocosm ('with crab' treatment). In the remaining replicates, no crab was added ('without crab' treatment). Crabs were allowed to feed under experimental conditions for $2 \mathrm{~d}$ and then were removed. Remaining clams were retrieved by lifting the mesh lining and sieving sediments in each mesocosm. Proportional mortality (PM) was determined for clams in each mesocosm; mean PM for each treatment was arcsinesquare-root-transformed (to homogenize variance: Underwood 1997) and compared by ANOVA using $\mathrm{O}_{2}$ level, year (fall 1999, summers 2000, 2001), and crabs (+ or - ) as factors. Temperature varied among years (Table 1).

Clam vertical migration. Clams collected from the Rhode River were transplanted into 2081 aquaria with 10 or 20 clams in 2 replicate aquaria per treatment (normoxic or low DO) in 1999 and with 10 clams in 4 replicate aquaria per treatment in 2001. Each tank had $20 \mathrm{~cm}$ of rinsed Rhode River muddy-sand sediment ( $12.5 \%$ silt and clay) and 13 ppt water to a depth of $30 \mathrm{~cm}$ above the sediment surface. A monofilament line above the sediment after acclimation from the original length of line. Subsequently, the aquaria were subjected to 2 treatments, normoxia $\left(>8 \mathrm{mg} \mathrm{O}_{2} \mathrm{l}^{-1}\right)$ and low over 3 to $4 \mathrm{~h}$ in the low DO aquaria. Normoxic and low DO conditions were achieved with bubbled air or an air and nitrogen mixture, respectively. In 1999, after 6, 12, $24,30,48,72$, and $147 \mathrm{~h}$ of DO treatment, clam burial depth was measured. For each tank, a single mean change in burial depth was estimated from the 10 or 20 clams, and the replicates of each treatment were used for comparison (ANOVA) between DO treatments. Additionally, we recorded the length of siphon exposed and any other notable behavioral changes in clams in 1999 when temperatures were 15 to $17^{\circ} \mathrm{C}$. Clams were considered dead if their siphons were lying flaccid on the sediment surface or if gaping shells were visible.

In 2001, final burial depth was determined after the $48 \mathrm{~h}$ DO treatment only. In addition, using heaters, the

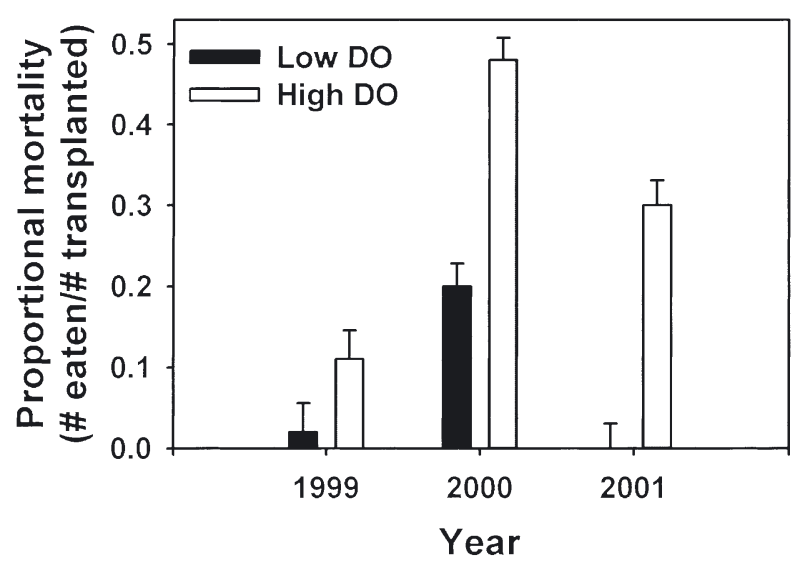

Fig. 2. Macoma balthica. Predator-induced proportional mortality under 2 hypoxia treatments (hypoxic, normoxic) in 3 years $(1999,2000,2001)$. In each year for each replicate, 12 clams were transplanted into a $0.25 \mathrm{~m}^{2}$ patch $(48$ clams $\mathrm{m}^{-2}$ ) in each mesocosm. DO: dissolved oxygen DO $\left(<2 \mathrm{mg} \mathrm{O}_{2} \mathrm{l}^{-1}\right)$. Oxygen levels were lowered slowly 
ambient water temperature within each tank was set to either $17^{\circ} \mathrm{C}$ (Trial 1) or $26^{\circ} \mathrm{C}$ (Trial 2). As in 1999, DO was normoxic (>8 $\mathrm{mg} \mathrm{l}^{-1}$ ) in 4 randomly selected aquaria, and hypoxic $\left(<2 \mathrm{mg} \mathrm{l}^{-1}\right)$ (with a 3 to $4 \mathrm{~h}$ adjustment period) in the remaining 4 aquaria. Water temperature and DO levels were measured and adjusted periodically to ensure maintenance of target levels. In 2001, change in burial depth was examined (2-way ANOVA) with DO treatment and temperature as factors. A final 2-way ANOVA using data from both years was conducted to compare differences in burial depth after $48 \mathrm{~h}$ of hypoxia as a function of DO and year.

\section{RESULTS}

\section{Crab-clam interactions}

Proportional mortality of clams was significantly higher under normoxia than hypoxia for all 3 years, regardless of ambient temperature (Fig. 2, Tables 1 \& 2). The $\mathrm{O}_{2} \times$ crab treatment interaction effect was significant (Table 2), precluding conclusions about the main effects and requiring 4 Student-Newman-Keuls (SNK) comparisons (Table 3). For the 'with crab' treatment, significantly more clams were eaten under normoxia $(35.6 \pm 10.1 \%)$ than under hypoxia $(8.9 \pm 4.2 \%)$. In the high DO treatment, the presence or absence of crab had a significant effect. Other SNK comparisons were not significantly different.

Clams in the 'without crab' treatment were retrieved within the $0.25 \mathrm{~m}^{2}$ plot area, demonstrating a lack of horizontal clam movement. No crabs died during the predation trials and all appeared healthy after the experiment. Crab position within the tanks changed daily, indicating movement, although they were not directly observed moving within mesocosms during the

Table 2. Macoma balthica. Three-way ANOVA of arcsine-, square-root-transformed proportional mortality $\mathrm{d}^{-1}$ from 1999, 2000, and 2001 mesocosm predation experiments. Factors consisted of DO treatment (hypoxic $=<2 \mathrm{mg} \mathrm{O}_{2} \mathrm{l}^{-1}$, normoxic $\left.=>8 \mathrm{mg} \mathrm{O}_{2} \mathrm{l}^{-1}\right)$, year $(1999,2000$, and 2001), and crab treatment (with or without crab). ${ }^{* * *} \mathrm{p}<0.005$; ${ }^{*} \mathrm{p}<0.05$;

$$
{ }^{n s} \mathrm{p}>0.05
$$

\begin{tabular}{|lcrcc|}
\hline Source of variation & SS & df & MS & $F$ \\
\hline $\mathrm{O}_{2}$ treatment & 0.3466 & 1 & 0.3466 & $4.31^{*}$ \\
Year & 0.3610 & 2 & 0.1805 & $2.25^{\text {ns }}$ \\
Crab treatment & 1.2291 & 1 & 1.2291 & $15.30^{* * *}$ \\
$\mathrm{O}_{2} \times$ Year & 0.0748 & 2 & 0.0374 & $0.47^{\text {ns }}$ \\
$\mathrm{O}_{2} \times$ Crab & 0.3465 & 1 & 0.3466 & $4.31^{*}$ \\
Year $\times$ Crab & 0.3610 & 2 & 0.1805 & $2.25^{\text {ns }}$ \\
$\mathrm{O}_{2} \times$ Year $\times$ Crab & 0.0748 & 2 & 0.0374 & $0.47^{\text {ns }}$ \\
Error & 2.5704 & 32 & 0.0803 & \\
& & & & \\
\hline
\end{tabular}

Table 3. Macoma balthica. Student-Newman-Keuls (SNK) comparisons of clam mortality from the interaction of DO treatment (hypoxic $=<2 \mathrm{mg} \mathrm{O}_{2} \mathrm{l}^{-1}$, normoxic $=>8 \mathrm{mg} \mathrm{O}_{2} \mathrm{l}^{-1}$ ) and crab Callinectes sapidus treatment (with or without crab) in 3-way ANOVA for mesocosm predation experiments. Given the non-significant year effect, the averages from all 3 years were used for SNK comparisons

\begin{tabular}{|llr|}
\hline Treatment & Comparison & p-value \\
\hline With crab & Normoxia $>$ low DO & $<0.01$ \\
Without crab & Normoxia = low DO & $\gg 0.1$ \\
Normoxia & With crab $>$ without crab & $<0.01$ \\
Low DO & With crab $=$ without crab & $\gg 0.1$ \\
\hline
\end{tabular}

day. Moreover, the mesocosms did not show changes on the surface of the sediment that would be indicative of changes in redox level (i.e. no white bacteria was growing during the $48 \mathrm{~h}$ predation period).

\section{Clam DO tolerance and vertical migration}

In the burial depth experiments, Macoma balthica survived well for the first $2 \mathrm{~d}$, but then began dying. After about $6 \mathrm{~d}$ (147 h) of hypoxia, 22 of 30 clams had survived. After $2 \mathrm{wk}, 20$ of the 30 hypoxic clams had survived, and after 3 wk, 3 of 30 had survived (Fig. 3).

In both 1999 and 2001, clam burial after $48 \mathrm{~h}$ of hypoxia did not differ appreciably from the $24 \mathrm{~h}$ acclimation depth, as clams rose in the sediment only slightly further under hypoxia $(0.52 \mathrm{~cm})$ compared to normoxia $(0.24 \mathrm{~cm})$. Clam burial depth did not differ significantly as a function of oxygen treatment, but did differ between years, and there was no interaction (2-way ANOVA: Table 4). Clams resided $\sim 0.5 \mathrm{~cm}$ deeper in the sediment in 1999 than in 2001, possibly due to more flocculent, softer sediments and larger

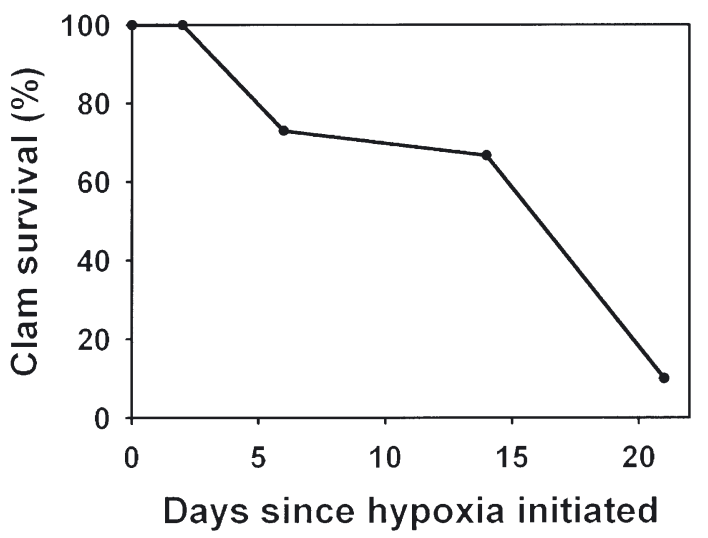

Fig. 3. Macoma balthica. Percent survival in hypoxic tanks versus days since hypoxia was initiated in 1999 burial-depth experimental tanks (10 or 20 clams per tank) 
Table 4. Macoma balthica. Two-way ANOVA of change in burial depth from depth at $24 \mathrm{~h}$ acclimation to depth after $48 \mathrm{~h}$ of oxygen treatment in the laboratory. Factors consisted of oxygen treatment (hypoxic $=<2 \mathrm{mg} \mathrm{O}_{2} \mathrm{l}^{-1}$, normoxic $=>8 \mathrm{mg}$ $\mathrm{O}_{2} \mathrm{l}^{-1}$ ) and year (1999 and 2001). ${ }^{* * *} \mathrm{p}<0.005 ;{ }^{\text {ns }} \mathrm{p}>0.05$

\begin{tabular}{|lcrcc|}
\hline Source of variation & SS & df & MS & $F$ \\
\hline $\mathrm{O}_{2}$ treatment & 0.208 & 1 & 0.208 & $0.58^{\text {ns }}$ \\
Year & 7.345 & 1 & 7.345 & $20.44^{* * *}$ \\
$\mathrm{O}_{2} \times$ Year & 0.029 & 1 & 0.029 & $0.08^{\text {ns }}$ \\
Error & 5.749 & 16 & 0.359 & \\
\hline
\end{tabular}

clams in 1999. Because different effects were tested in each year (prolonged hypoxia in 1999, temperature in 2001), both years were examined separately.

In 1999, mean $( \pm \mathrm{SE})$ burial depth of Macoma balthica after $24 \mathrm{~h}$ acclimation in normoxia was $-5.82 \pm 1.39 \mathrm{~cm}$ and after $71 \mathrm{~h}$ of normoxia it was $-7.13 \pm 1.13 \mathrm{~cm}$ (not significantly different than $24 \mathrm{~h}$ acclimation [ANOVA; $\mathrm{p}=0.622]$ ). After $48,71,78$, and $147 \mathrm{~h}$ of hypoxia, burial depth was not significantly different from acclimation depth (Fig. 4; ANOVAs: 48 h, p =0.885; 78 h, p = $0.834 ; 147 \mathrm{~h}, \mathrm{p}=0.614$ ), and clams did not reduce bur-

(a) Hypoxic

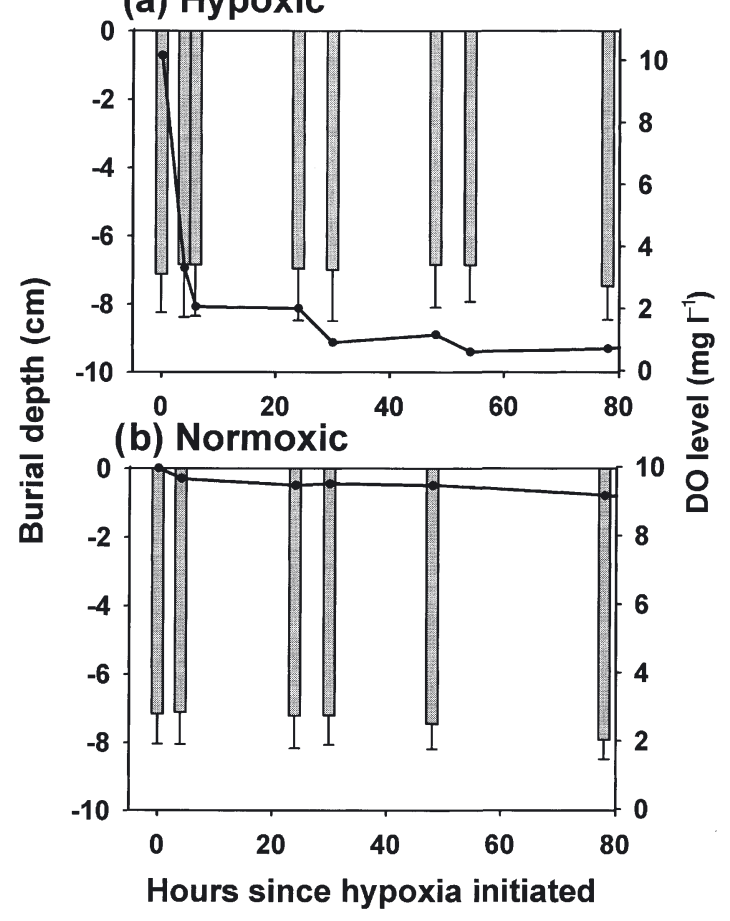

Fig. 4. Macoma balthica. Burial depth and hypoxia level in (a) hypoxic aquaria and (b) normoxic aquaria over time in 1999 (10 or 20 clams per tank). $0 \mathrm{~h}$ since hypoxia = measurements after $71 \mathrm{~h}$ acclimation period. Bars indicate mean (-1 SE) burial depth; line and data points indicate mean dissolved oxygen level

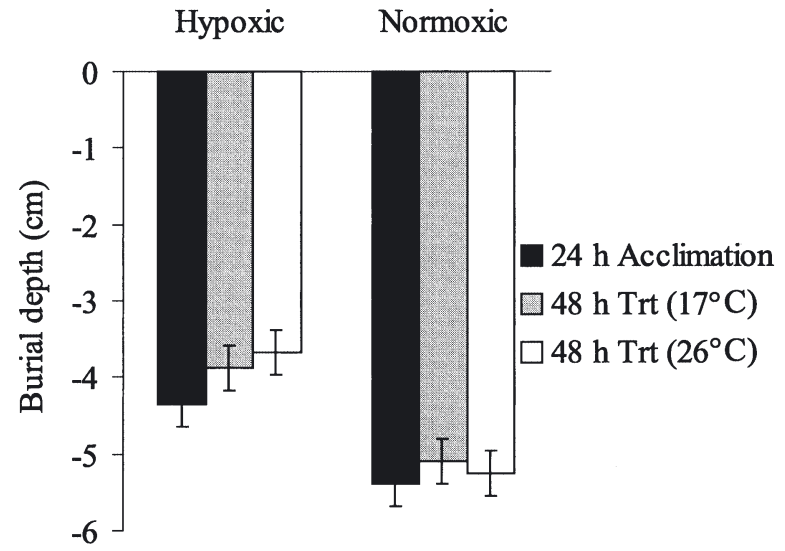

Fig. 5. Macoma balthica. Mean ( $\pm 1 \mathrm{SE})$ burial depth after $24 \mathrm{~h}$ acclimation (normoxia) and after $48 \mathrm{~h}$ of hypoxic or normoxic treatments (Trt) at 2 temperatures in 2001 (10 clams per tank)

ial depth until just before death. Redox potential (Eh) was not measured, but hypoxic tanks smelled of sulfur and had white bacteria on their surfaces.

In 2001, at the end of $24 \mathrm{~h}$ acclimation, clams had buried to a mean depth of $-4.9 \pm 1.2 \mathrm{~cm}$, and following the $24 \mathrm{~h}$ acclimation period, overall vertical movement averaged an additional $0.4 \pm 0.6 \mathrm{~cm}$ rise in the sediment (Fig. 5). This minimal movement was not affected by temperature or dissolved oxygen, and there was no interaction (2-way ANOVA; Table 5). The burial depths may have been shallower than those in the field, since there were no predators in the tanks.

\section{Clam siphon extension}

In hypoxic aquaria in 1999, the length of Macoma balthica siphons stretched upward into the water column increased with increasing duration of hypoxia (Fig. 6). In normoxic aquaria, siphons were observed stretching horizontally across the sediment surface (a typical feeding activity: Lin \& Hines 1994) but never vertically upward into the water column. Siphon extension did not occur during the first $8 \mathrm{~h}$ after the initi-

Table 5. Macoma balthica. Two-way ANOVA of effects of oxygen treatment $\left(\right.$ hypoxic $=<2 \mathrm{mg} \mathrm{O}_{2} \mathrm{l}^{-1}$, normoxic $=>8 \mathrm{mg}$ $\mathrm{O}_{2} \mathrm{l}^{-1}$ ) and temperature $\left(17\right.$ and $\left.26^{\circ} \mathrm{C}\right)$ on vertical movement in $2001 .{ }^{n s} \mathrm{p}>0.05$

\begin{tabular}{|llrlr|}
\hline Source of variation & \multicolumn{1}{c}{ SS } & df & MS & $F$ \\
\hline $\mathrm{O}_{2}$ treatment & 0.49 & 1 & 0.49 & $1.48^{\text {ns }}$ \\
Temperature & 0.0025 & 1 & 0.0025 & $0.01^{\text {ns }}$ \\
$\mathrm{O}_{2} \times$ Temperature & 0.1225 & 1 & 0.1225 & $0.37^{\text {ns }}$ \\
Error & 3.985 & 15 & 0.55 & \\
\hline
\end{tabular}




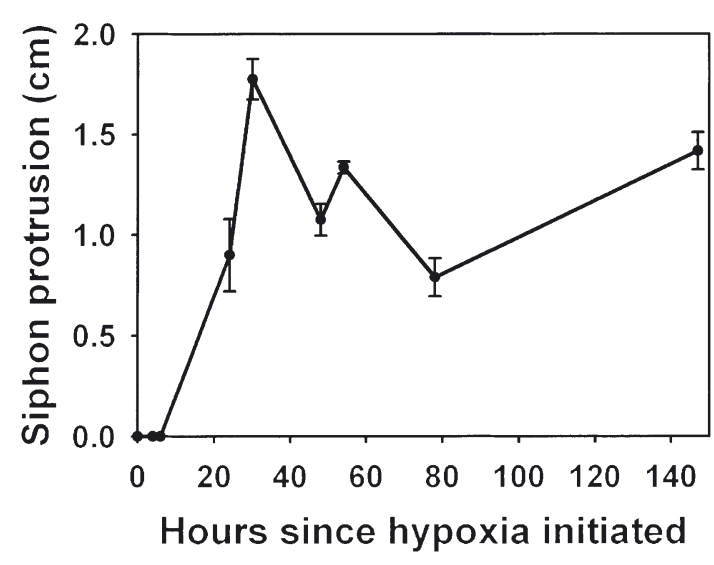

Fig. 6. Macoma balthica. Mean ( $\pm 1 \mathrm{SE}$ ) length of siphon protrusion above sediment surface versus number of hours since hypoxia was initiated in hypoxic aquaria in 1999 (10 or 20 clams per tank). Vertical protrusion of siphons in normoxic aquaria was negligible

ation of hypoxia, but increased to $1.78 \mathrm{~cm}$ after $30 \mathrm{~h}$. At $30 \mathrm{~h}$ hypoxia, the length of the siphon extended was significantly greater in hypoxic than normoxic tanks (ANOVA: $\mathrm{p}=0.016$ ). The siphon extension rate was $0 \mathrm{~cm} \mathrm{~h}^{-1}$ during the first $8 \mathrm{~h}$ and $0.08 \mathrm{~cm} \mathrm{~h}^{-1}$ from 8 to $30 \mathrm{~h}$ of exposure to hypoxia. In 2001, similar siphon extension in response to low DO was observed but not quantified.

\section{DISCUSSION}

This investigation constitutes a quantitative test of changes in predator-prey interactions associated with low dissolved oxygen in benthic habitats of Chesapeake Bay. In our outdoor mesocosm experiments, proportional mortality of clams by crabs was greater under normoxia than hypoxia, indicating that the crabs were more adversely affected by hypoxia than the clams. Moreover, in burial-depth experiments, Macoma balthica did not migrate to the sediment surface in response to hypoxia. Rather, clams remained stationary and only moved to the surface immediately before death after $\sim 2$ to $3 \mathrm{wk}$ of hypoxia. This suggests that the lowered mortality under hypoxia is due to crab behavioral changes in the absence of clam behavioral changes. Thus, hypoxia adversely affects the predatorprey interaction between Callinectes sapidus and M. balthica, which may have serious implications for trophic dynamics in Chesapeake Bay.

The Chesapeake Bay population of Macoma balthica is tolerant of short-term hypoxia, since no mortality occurred during $48 \mathrm{~h}$ of low DO. Although $75 \%$ of clams survived for $6 \mathrm{~d}, 90 \%$ had died after $3 \mathrm{wk}$ of low
DO. This is comparable to $90 \%$ mortality of $M$. balthica and M. mitchelli after $3 \mathrm{wk}$ of hypoxia in field sites in North Carolina (Buzzelli et al. 2002). Many clams, however, remained buried at approximately their initial burial depth until death in our experiments. The possibility remains that there were sublethal effects of hypoxia upon clams, such as reduced somatic growth or effects upon reproduction (Nilsson \& Sköld 1996) that we did not measure. Overall, our data suggest that M. balthica in Chesapeake Bay is quite tolerant of changes in dissolved oxygen for a period of days to weeks, which is an exposure interval typical for several subestuaries of the bay. For example, $7 \mathrm{~d}$ is the mean duration for an hypoxic event in the York River (Officer et al. 1984). Thus, under short-lived hypoxia, trophic transfer from $M$. balthica to blue crabs may be reduced rather than enhanced.

The behavioral response of Macoma balthica was not a reduction in burial depth, as in the soft-shelled clam Mya arenaria (Taylor \& Eggleston 2000), but rather an extension of siphons into the water column after $30 \mathrm{~h}$ of hypoxia. This siphon extension was probably an effort to reach higher oxygen levels further up in the water above the sediment-water boundary layer; for example, Macoma balthica can survive 9 wk under algal mats by extending siphons to normoxic overlying waters (Thiel et al. 1998). Similarly, limb extension under hypoxia has been seen in brittle stars (Nilsson \& Sköld 1996). The siphon extension rates of $M$. balthica we observed were substantially slower than those of M. arenaria, which extends its siphons $2 \mathrm{~cm}$ into the water column after only 4 to $8 \mathrm{~h}$ of hypoxia (Taylor \& Eggleston 2000). M. balthica's siphon extension in our experiments occurred soon enough after the onset of hypoxia ( 8 to $30 \mathrm{~h}$ ) to allow siphon-nipping by crabs in the experimental mesocosms. However, little siphonnipping probably occurred and probably did not reduce clam burial depth, as little predation-induced mortality was observed under hypoxia.

As a caveat, siphon-extension behavior along with maintenance of burial depth (observed in laboratory aquaria) may be possible only in the absence of siphonnipping fishes. In the field, siphons extended into the water column can be nipped by fishes and crabs (Hines et al. 1990, Peterson \& Skilleter 1994). When siphons are nipped and siphon length decreases, the clams must move closer to the sediment surface to feed successfully (Lin \& Hines 1994, de Goeij et al. 2001). The reduction in clam burial depth would leave clams more susceptible to predation by blue crabs feeding with tactile search mechanisms (Hines et al. 1995, Clark et al. 1999a,b). Therefore, in the field, if fishes can withstand exposure and enter hypoxic zones, they may be able to nip siphons and reduce clam burial depth, indirectly increasing blue crab detection of and predation upon clams. 
Sediment chemistry can greatly influence the response of macrofauna to hypoxia, and tolerance may depend on the exposure of each population within its specific habitat. Macoma balthica acclimated to high sulfide conditions shows high survival during sulfide exposure (Jahn \& Theede 1997). Adult M. balthica can detoxify sulfide by oxidation to thiosulfate, although young $M$. balthica may be adversely affected by it (Jahn et al. 1997). Although we did not measure redox potential (Eh) or sulfide concentrations, moderate hypoxia (>1.8 $\mathrm{mg} \mathrm{l}^{-1}$ ) may not alter Eh in tanks with recirculating seawater (Nilsson \& Sköld 1996), as in our predation mesocosm tanks.

We examined the effects of short-lived hypoxia on benthic trophic transfer, thus providing a comparison to a benthic predator-prey system with a relatively intolerant mollusk prey (Mya arenaria; Taylor \& Eggleston 2000), to a European benthic community (Pearson \& Rosenberg 1992), to an epifaunal community (Sagasti et al. 2001), and also to a pelagic predatorprey system (Breitburg et al. 1997). Similar to the reduction in blue crab predation upon Macoma balthica under hypoxia in our experiment, Taylor \& Eggleston (2000) reported lower consumption by blue crabs of $M$. arenaria despite the clams' migration toward the sediment surface under hypoxia. Also, in the SE Kattegat, hypoxia reduced epifaunal predation by $\sim 17$ to $23 \%$ of normal levels in some predatory shrimp and crab species (Pearson \& Rosenberg 1992). In a pelagic study, immobile fish eggs displayed decreased mortality under hypoxic stress due to reduced mobility of sea nettle predators (Breitburg 1992, Breitburg et al.1997). Thus, reduced predation under hypoxia in both pelagic and benthic ecosystems agrees with consumer stress models (e.g. Menge \& Sutherland 1987, Seitz 1998). Moreover, areas subject to short-term hypoxia may serve as prey refuges if the hypoxia is more stressful to the predators than to the prey (Menge \& Sutherland 1987), as in our study.

This decrease in predator-induced mortality may initially decrease the overall transfer of benthic production to higher trophic levels, but if hypoxia is prolonged (i.e. $>3 \mathrm{wk}$ ), mortality on the surface could increase trophic transfer. Alternatively, the mass mortality of infauna in response to severe prolonged hypoxia would be expected to decrease trophic transfer over the long term, as affected zones become devoid of prey (Holland et al. 1977, Stachowitsch 1984).

Increases in eutrophication of coastal zones has led to increases in the duration and areal extent of hypoxia (Rosenberg \& Loo 1988, Diaz \& Rosenberg 1995), particularly in estuarine systems such as Long Island Sound, Chesapeake Bay, and the Gulf of Mexico. Shallow systems such as Long Island Sound and the Gulf of Mexico (Rabalais et al. 1991) experience bouts of hypoxia similar to those in Chesapeake Bay; therefore, the benthic predator-prey systems may be similarly affected. A demonstration of the detrimental impact of hypoxia on trophic transfer within the Chesapeake Bay benthic system can serve as a model for other estuarine systems worldwide.

Acknowledgements. We are grateful to R. Lipcius for intellectual contributions leading to development of the hypotheses and results herein. We also thank the staff and students at the Smithsonian Environmental Research Center and Morgan State University who contributed to this work. We are particularly grateful to summer interns K. Henley (Morgan State University) and K. Van Eron (Virginia Governor's School), who were instrumental in conducting the experiments. We acknowledge funding from Maryland Sea Grant, NOAA National Sea Grant, Smithsonian Environmental Studies Program, and the National Science Foundation (OCE 9730923 and 9810624). This is contribution 2551 from the Virginia Institute of Marine Science.

\section{LITERATURE CITED}

Baden SP, Loo LO, Pihl L, Rosenberg R (1990) Effects of eutrophication on benthic communities including fish: Swedish west coast. Ambio 19:113-122

Baird D, Ulanowicz RE (1989) The seasonal dynamics of the Chesapeake Bay ecosystem. Ecol Monogr 59:329-361

Beukema JJ, Meehan BW (1985) Latitudinal variation in linear growth and other shell characteristics of Macoma balthica. Mar Biol 90:27-33

Breitburg DL (1992) Episodic hypoxia in Chesapeake Bay: interacting effects of recruitment, behavior, and physical disturbance. Ecol Monogr 62:525-546

Breitburg DL, Loher T, Pacey CA, Gerstein A (1997) Varying effects of low dissolved oxygen on trophic interactions in an estuarine food web. Ecol Monogr 67:489-507

Buzzelli CP, Leuttich RA Jr, Powers SP, Peterson CH, McNinch JE, Pinckney JL, Pearl HW (2002) Estimating the spatial extent of bottom-water hypoxia and habitat degradation in a shallow estuary. Mar Ecol Prog Ser 230: 102-112

Clark ME, Wolcott TG, Wolcott DL, Hines AH (1999a) Foraging and agonistic activity co-occur in free-ranging blue crabs (Callinectes sapidus): observation of animals by ultrasonic telemetry. J Exp Mar Biol Ecol 233:143-160

Clark ME, Wolcott TG, Wolcott DL, Hines AH (1999b) Intraspecific interference among foraging blue crabs Callinectes sapidus: interactive effects of predator density and prey patch distribution. Mar Ecol Prog Ser 178:69-78

Das T, Stickle WB (1993) Sensitivity of crabs Callinectes sapidus and $C$. similus and the gastropod Stramonita haemastoma to hypoxia and anoxia. Mar Ecol Prog Ser 98: $263-274$

Das T, Stickle WB (1994) Detection and avoidance of hypoxic water by juvenile Callinectes sapidus and C. similis. Mar Biol 120:593-600

Dauer DM, Rodi AJ Jr, Ranasinghe JA (1992) Effects of low dissolved oxygen events on the macrobenthos of the lower Chesapeake Bay. Estuaries 15:348-391

de Goeij P, Luttikhuizen PC, van der Meer J, Piersma T (2001) Facilitation on an intertidal mudflat: the effect of siphon nipping by flatfish on burying depth of the bivalve Macoma balthica. Oecologia 126:500-506 
Diaz RJ, Rosenberg R (1995) Marine benthic hypoxia: a review of its ecological effects and the behavioural responses of benthic macrofauna. Oceanogr Mar Biol Annu Rev 33:245-303

Diaz RJ, Neubauer RJ, Schaffner LC, Pihl L, Baden SP (1992) Continuous monitoring of dissolved oxygen in an estuary experiencing periodic hypoxia and the effect of hypoxia on macrobenthos and fish. Sci Total Environ (Suppl 1992): 1055-1068

Dries RR, Theede H (1974) Sauerstoffmangelresistenz mariner Bodenvertebraten aus der westlichen Ostsee. Mar Biol 25: 327-333

Ebersole EL, Kennedy VS (1995) Prey preferences of blue crabs Callinectes sapidus feeding on 3 bivalve species. Mar Ecol Prog Ser 118:167-177

Eggleston DB, Lipcius RN, Hines AH (1992) Density-dependent predation by blue crabs upon infaunal clam species with contrasting distribution and abundance patterns. Mar Ecol Prog Ser 85:55-68

Haas LW (1977) The effect of spring-neap tidal cycle on the vertical structure of the James, York and Rappahannock rivers, Virginia, USA. Estuar Coast Mar Sci 5:485-496

Hagy JD (2002) Eutrophication, hypoxia and trophic transfer in Chesapeake Bay. PhD thesis, University of Maryland, Center for Environmental Science, Solomons

Henriksson R (1969) Influence of pollution on the bottom fauna of the sound (Øresund). Oikos 20:507-523

Hines AH, Comtois KL (1985) Vertical distribution of infauna in sediments of a subestuary of central Chesapeake Bay. Estuaries 8:296-304

Hines AH, Haddon AM, Wiechert LA (1990) Guild structure and foraging impact of blue crabs and epibenthic fish in a subestuary of Chesapeake Bay. Mar Ecol Prog Ser 67: $105-126$

Hines AH, Wolcott TG, González-Gurriarán E, GonzálezGurriarán JL, Friere J (1995) Movement patterns and migrations in crabs: telemetry studies of juvenile and adult behavior in Callinectes sapidus and Maja squinado. J Mar Biol Assoc UK 75:27-42

Holland AF, Mountford NK, Mihursky J (1977) Temporal variation in upper bay and mesohaline communities. I. The 9-m mud habitat. Chesapeake Sci 18:370-378

Holland AF, Shaughnessy AT, Hiegal M (1987) Long-term variation in mesohaline Chesapeake Bay macro-benthos: spatial and temporal patterns. Estuaries 10:227-245

Jahn A, Theede H (1997) Different degrees of tolerance to hydrogen sulphide in populations of Macoma balthica (Bivalvia, Tellinidae). Mar Ecol Prog Ser 154:185-196

Jahn A, Janas U, Theede H, Szaniawska A (1997) Significance of body size in sulphide detoxification in the Baltic clam Macoma balthica. Mar Ecol Prog Ser 154:175-183

Jørgensen BB (1980) Seasonal oxygen depletion in the bottom waters of a Danish fjord and its effects on the benthic community. Oikos 34:68-76

Lenihan HS, Peterson CH, Beyers JE, Grabowski JH, Thayer GH, Colby DR (2001) Cascading effects of habitat degradation: oyster reefs invaded by refugee fishes escaping stress. Ecol Appl 11:764-782

Lin J, Hines AH (1994) Effects of suspended food availability on the feeding mode and burial depth of the Baltic clam, Macoma balthica. Oikos 69:28-36

Llansó R J (1992) Effects of hypoxia on estuarine benthos: the lower Rappahannock river (Chesapeake Bay), a case study. Estuar Coast Shelf Sci 35:491-515

Mansour RA (1992) Foraging ecology of the blue crab, Callinectes sapidus Rathbun, in lower Chesapeake Bay. PhD thesis, College of William and Mary, Virginia Institute of Marine Science, Gloucester Point
Meehan BW, Carlton JT, Wenne R (1989) Genetic affinities of the bivalve Macoma balthica from the Pacific coast of North America: evidence for recent introduction and historical distribution. Mar Biol 102:235-241

Menge BA, Sutherland JP (1987) Community regulation: variation in disturbance, competition, and predation in relation to environmental stress and recruitment. Am Nat 130: $730-757$

Nestlerode JA, Diaz RJ (1998) Effects of periodic environmental hypoxia on predation of a tethered polychaete, Glycera americana: implications for trophic dynamics. Mar Ecol Prog Ser 172:185-195

Nilsson HC, Rosenberg R (1994) Hypoxic response of two marine benthic communities. Mar Ecol Prog Ser 115: 209-217

Nilsson HC, Sköld M (1996) Arm regeneration and spawning in the brittle star Amphiura filiformis (O.F. Müller) during hypoxia. J Exp Mar Biol Ecol 199:193-206

Officer CB, Biggs RB, Taft JL, Cronin LE, Tyler MA, Boyton WR (1984) Chesapeake Bay anoxia: origin, development, and significance. Science 223:22-27

Pearson TH, Rosenberg R (1992) Energy flow through the SE Kattegat: a comparative examination of the eutrophication of a coastal marine ecosystem. Neth J Sea Res 28:317-334

Peterson CH, Skilleter GA (1994) Control of foraging behavior of individuals within an ecosystem context: the clam Macoma balthica, flow environment, and siphon-cropping fishes. Oecologia 100:256-267

Pihl L (1989) Effects of oxygen depletion on demersal fish in coastal areas of the south-east Kattegat. In: Ryland JS, Tyler PA (eds) Proceedings of the 23rd European Marine Biology Symposium. Olsen \& Olsen, Fredensborg, p 431-439

Pihl L, Baden SP, Diaz RJ (1991) Effects of periodic hypoxia on distribution of demersal fish and crustaceans. Mar Biol 108:349-360

Pihl L, Baden SP, Diaz RJ, Schaffner LC (1992) Hypoxiainduced structural changes in the diet of bottom-feeding fish and Crustacea. Mar Biol 112:349-361

Rabalais NN, Turner RE (eds) (2001) Coastal hypoxia: consequences for living resources and ecosystems. Coastal and Estuarine Studies, Vol 58. American Geophysical Union, Washington, DC

Rabalais NN, Turner RE, Wiseman WJ, Boesch DF (1991) A brief summary of hypoxia on the northern Gulf of Mexico continental shelf: 1985-1988. In: Tyson RV, Pearson TH (eds) Modern and ancient continental shelf anoxia, Spec Publ 58. Geological Society, London, p 35-47

Rabalais NN, Wiseman WJ, Turner RE (1994) Comparison of continuous records of near-bottom dissolved oxygen from the hypoxia zone of Louisiana. Estuaries 17:850-861

Rosenberg R, Loo LO (1988) Marine eutrophication induced oxygen deficiency: effects on soft bottom fauna, west Sweden. Ophelia 29:213-225

Sagasti A, Schaffner LC, Duffy JE (2001) Effects of periodic hypoxia on mortality, feeding, and predation in an estuarine epifaunal community. J Exp Mar Biol Ecol 258: $257-283$

Seitz RD (1998) Incorporation of soft-sediment systems into a model of marine benthic community regulation. Mar Freshw Res 49:817-826

Seitz RD, Lipcius RN, Hines AH, Eggleston DB (2001) Density-dependent predation, habitat variation, and the persistence of marine bivalve prey. Ecology 82:2435-2451

Seliger HH, Boggs JA, Biggley JA (1985) Catastrophic anoxia in the Chesapeake Bay in 1984. Science 1984:70-73

Stachowitsch M (1984) Mass mortality in the Gulf of Trieste: the course of community destruction. Mar Ecol 5:243-264 
Steimle FW Jr, Radosh DJ (1979) Effects on the benthic invertebrate community. In: Swanson RL, Sindermann CJ (eds) Oxygen depletion and associated benthic mortalities in the New York Bight, 1976, Prof Pap 11. National Oceanic and Atmospheric Administration, Washington, DC, p 281-293

Tallqvist M (2001) Burrowing behaviour of the Baltic clam Macoma balthica: effects of sediment type, hypoxia, and predator presence. Mar Ecol Prog Ser 212:183-191

Taylor D, Eggleston DB (2000) Effects of hypoxia on an estuarine predator-prey interaction: mutual interference and foraging behavior of the blue crab (Callinectes sapidus) on

Editorial responsibility: Otto Kinne (Editor),

Oldendorf/Luhe, Germany infaunal clam prey (Mya arenaria). Mar Ecol Prog Ser 196: 221-237

Thiel M, Stearns LM, Watling L (1998) Effects of green algal mats on bivalves in a New England mud flat. Helgol Meeresunters 52:15-28

Underwood AJ (1997) Experiments in ecology: their logical design and interpretation using analysis of variance. Cambridge University Press, Cambridge

Weigelt M, Rumohr H (1986) Effects of wide-range oxygen depletion on benthic fauna and demersal fish in Kiel Bay 1981-1983. Meeresforschung 31:124-136

Submitted: September 13, 2002; Accepted: April 17, 2003

Proofs received from author(s): July 28, 2003 